\title{
Towards new commons and sharing interests in the landscape, integrating natural and cultural heritage
}

\section{Bas Pedroli}

Wageningen University \& Research, the Netherlands

\begin{abstract}
Heritage values represent a common good, contributing to societal identity. Landscape is a topical issue because it represents character and identity in both a spatial and a temporal dimension, uniting natural and cultural aspects of heritage at the same time. Especially in Europe, practically all natural heritage can be considered cultural heritage as well, since it is through human action that Europe's biodiversity has evolved. Heritage perspectives on landscape and nature underline time depth, human agency and social value within landscape. Its cultural starting point does not marginalise nature, but places nature within cultural filters, thus highlighting the reciprocity of nature and culture in the creation of sustainable places. Today's changing society is transitioning towards new forms of governance dominated by collaboration and continuously shifting networks or actors. Reported examples of cultural landscapes explore heritage management approaches that benefit from combining natural and cultural heritage perceptions. In this context, commonly accessible heritage can bring people together in joint efforts to use the inherited landscape as a shared and cherished resource rather than a conserved and regulated landscape.
\end{abstract}

Keywords: Perception, Transition, Access, Governance, Common Good

Introduction: The challenge of a living landscape based on cultural and natural heritage Traditional European landscapes represent multiple layers of natural and cultural heritage that can hardly be accounted for by science or policy (Palang \& Fry 2003). European landscapes characterise a small continent impacted by a large range of climatic conditions, and affected by Central Asian, Atlantic, Arctic and African biological influences. Geological and geomorphological features led to strongly variable soils, reflected in a highly diverse flora and fauna. While accommodating to their environment, since prehistoric times people settled in Europe. They have significantly added to the remarkable diversity of landscapes, now representing a convoluted manifestation of cultural and natural heritage (Fig. 1). Over time, a large multiplicity of communities, social constructs and customs evolved, creating the great diversity of European landscapes (Pedroli et al. 2016).

A large part of the cultural and natural heritage represented by this diversity of landscapes is not being sustained by current land use since the land use has undergone multiple transitions following societal developments, cultural changes, agricultural innovations and land reforms (Pinto Correia et al. 2018). Therefore, gradual or abrupt transformations in the landscape have occurred throughout history. In fact, transformations are also inevitable in the future because a landscape that remains the same is no longer a living landscape and is, in the best case, doomed to survive as a museum landscape (Priore 2009). Today, landscape is often used 


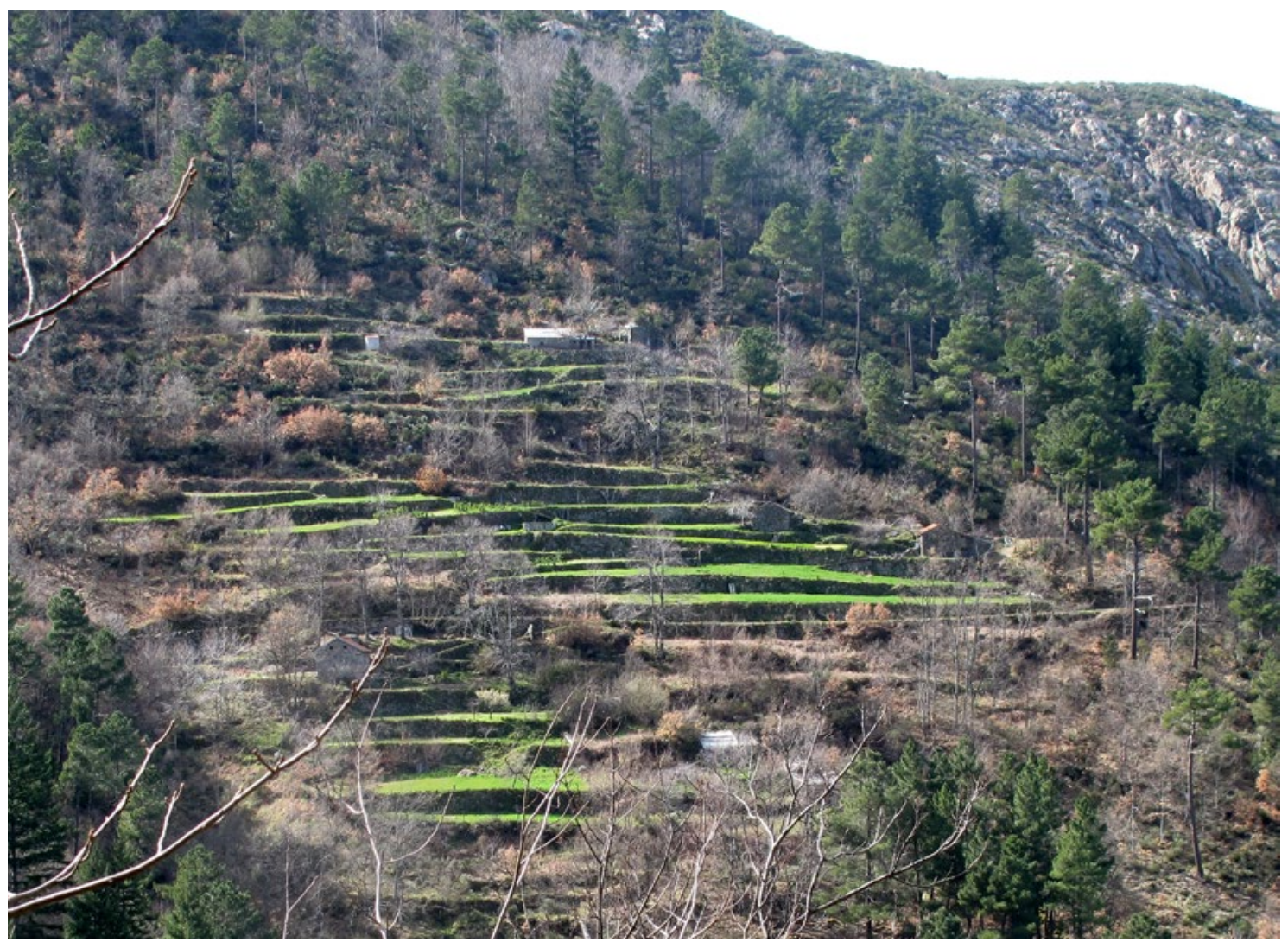

Figure 1. Terraced landscape in the Serra do Estrela, Portugal: convolution of cultural and natural heritage, today in a process of abandonment.

as a gadget by the privileged who can afford to buy houses that look out over beautiful scenery, but at the same time, the everyday landscape provides (subconscious) identity to its inhabitants (Stobbelaar \& Pedroli 2011).

Heritage may very well be re-appropriated as an identity carrier for new inhabitants, be it second-homers, tourists or even migrants (González 2015), although the darker side of history is often difficult to forget and can lead to new misunderstandings as is recently captured in the concept of dissonant heritage (Lähdesmäki et al. 2019). Vanishing landscapes, i.e. landscapes that lose their characteristic elements and features, are essentially the consequence of unintended side-effects of land use change. These landscapes are reported everywhere in Europe: the degradation or vanishing of ancient field patterns and roads, archaeological rudiments, land management structures, farm buildings, and irrigation and drainage systems (Pinto Correia et al. 2018: 64). Associated social and communal landscape management systems and narratives often degrade or disappear as well.

Within this context, the objective of this paper is to reflect on the value of natural and cultural heritage embedded in landscape and the potential role heritage can play in envisioning future living landscapes in Europe.

\section{Natural and cultural heritage, do we really cherish them?}

Human management of the landscape - even if low-impact - has been present for thousands of years, even in remote and seemingly untouched nature (Holtmeier \& Broll 2005). The agricultural history of Europe started long before historical sources began to document the 
European civilisations of the sixth century BC (Pounds 1990: 9). Therefore, it is difficult to distinguish between cultural and natural heritage, although the two disciplinary fields are often far apart, not only in Europe but all over the world, and symbolised by the Convention on Biological Diversity on the one side, and the UNESCO World Heritage list on the other (Agnoletti \& Rotherham 2015). The term biocultural diversity has been coined to overcome this challenge (Elands \& Van Koppen 2012; Agnoletti \& Emanueli 2016; Elands et al. 2018), but sectorial policies are dominant over cross-sectoral issues everywhere and conflicts over priorities easily arise, such as: How important is it to preserve historic farm buildings and settlement structures with associated land use patterns, even if not economic anymore? Can land abandonment in specific cases also be welcomed as an opportunity for the reappearance of animal species that vanished from the area long ago? Or even more difficult, given the limited resources, can the consequences of urgent societal demands such as continuing urban development, increasing mobility, and intensifying agriculture be considered acceptable, specifically regarding the trade-offs for cultural and natural heritage? This is the more relevant question, since landscape, as the logical expression of cultural and natural heritage, is generally not viewed as a separate sector in national policies, and certainly not in the European Union (EU henceforth) (Pedroli et al. 2016).

The EU has no competence in landscape nor in spatial planning, while practically all policies of the EU - agriculture, energy, climate, transport, urbanisation - have direct consequences for landscape and heritage. For example, within the framework of the Common Agricultural Policy if the EU since the 1980s, stimulating measures on forestation, the conversion of grazing land to cropland, scale enlargement etc. have led to important landscape changes across Europe, e.g. in the Mediterranean (Serra, Pons \& Saurí 2008) and in mountainous areas (MacDonald et al. 2000). This poses a large threat to sustainable landscape management; numerous further examples of unintended and generally avoidable negative landscape impacts exist, caused by sectoral developments (see Antrop 2004; May 2015; Plieninger et al. 2016). Since these "unseen" landscape changes (Pinto Correia et al. 2018: 64-109) tend to diminish landscape diversity, implying a decrease in biodiversity and cultural identity as well, large challenges exist for a more holistic approach to sustainable landscape management (Plieninger et al. 2015; Antrop \& Van Eetvelde 2017).

These trends lead to polarised land use, characterised by land sparing: highly efficient production oriented spaces versus small scale peri-urban multifunctional landscapes (Metzger et al. 2018) in which the traditional family farm - characteristic for European agriculture - is likely to disappear within a few generations due to the increasing importance of market-oriented land and product pricing in a global context. Cultural and natural heritage embedded in landscapes are threatened by uncontrolled land abandonment, biodiversity decrease, loss of ecosystem and landscape services, and declining rural liveability (Van der Sluis et al. 2015). However, stakeholders and civil society alike express the wish for a different future (Pérez-Soba et al. 2018). "We don't get what we want!" (Pedroli et al. 2015). By developing and supporting visions for societal development that go beyond four years of the regular electoral mandate of most European parliaments, today's process of democratic decision making does not seem to be optimally tuned to safeguard natural and cultural heritage in the landscape. 


\section{Towards new commons}

Are natural and cultural heritage common goods? In the increasingly market-oriented societies of today's Europe, politicians often claim that if people really care about heritage values they should also be willing to pay for them. However, since the individual willingness to pay for public goods is not by definition proportional to the perceived values of heritage, this increasingly leads to market failure, and thus degradation of heritage (Cooke \& Moon 2015). The political economist Elinor Ostrom received the Nobel Prize in 2009 for "her analysis of economic governance, especially the commons" (Mandl 2019: 171). When Ostrom published Governing the Commons (Ostrom 1990), one could not have imagined how her ideas about community-based development, self-organisation, self-governance and actornetworks would be extensively cited. Yet, in practice, bringing these ideas to our current socio-economic context remains a highly relevant societal and political challenge.

In 1968, the American ecologist Garrett Hardin in Tragedy of the Commons (Hardin 1968) drew attention to two human factors that drive environmental change:

"The first factor is the increasing demand for natural resources and environmental services, stemming from growth in human population and per capita resource consumption. The second factor is the way in which people organise themselves to extract resources from the environment and eject effluents into it - what social scientists refer to as 'institutional arrangements'. Hardin's work has been bighly influential but has long been aptly criticised as being oversimplified." (Dietz et al. 2003: 1907).

One of the issues is that many social groups (such as herders on the commons both in Atlantic and arctic lowlands and in alpine areas) successfully avoided resource degradation, over many centuries, by maintaining self-governing, sustainable institutions, precisely the type of common management that Hardin claimed was ineffective; it was only when these systems became disrupted by external private or state ownership that 'tragedy' ensued (Dietz et al. 2003).

Inspired by Ostrom's intellectual legacy, cultural as well as natural heritage may serve as the material and semiotic spark for strategies that will generate opportunities for development that are based on user rights. Today's constantly shifting networks of relationships co-create new social arrangements, as suggested by Actor-Network Theory (Latour 2004). This will create new economic prospects, enhance business models, and also encourage approaches that stimulate involvement and further integration of social groups in new rural commons. As a result, rural areas will have increased social cohesion, a better social climate, and improved living conditions. Collaboration between citizens, entrepreneurs and democratic institutions is increasingly being recognised as beneficial for successful rural land use planning (Dietz et al. 2003). This is reflected in recent changes to EU rural development policy that makes funds available for different forms of collaboration, including environmental management in agricultural landscapes.

Within the research of the commons, substantial theoretical and conceptual innovations are to be expected from inter- and transdisciplinary reflections on the applicability of the concepts of deep-mapping (Fagerholm \& Käyhkö 2009; Bodenhamer et al. 2013; Roberts 2016) and place-making (Beilin \& Bohnet 2015; Buttimer 2015; Primdahl \& Kristensen 2016) to community-based governance modes for societal transformation in landscapes that represent substantial natural and cultural heritage. 


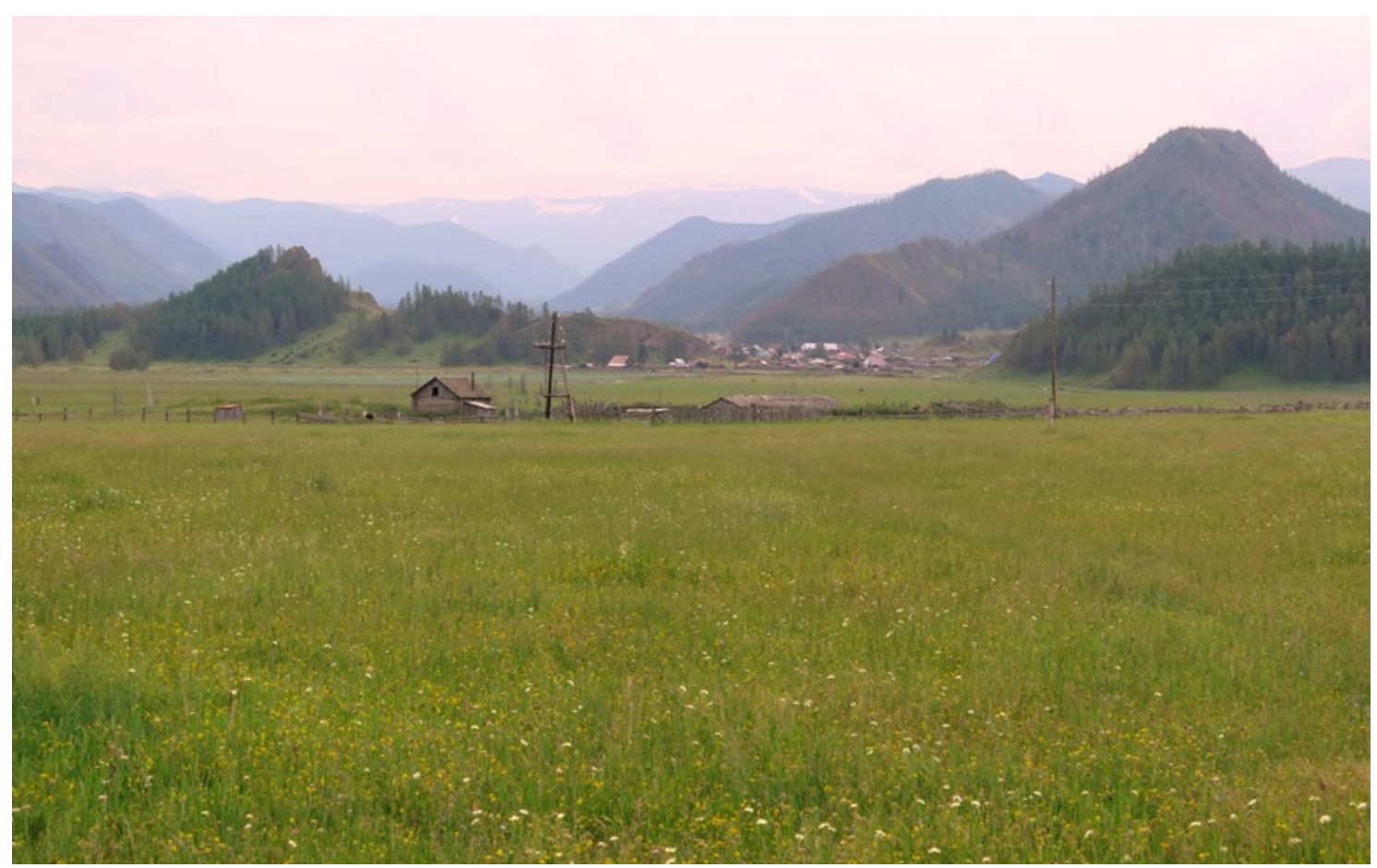

Figure 2. The commons in the Karakol Valley, Altay, South-Siberia.

\section{Change of paradigm needed for a reappraisal of the commons}

The earliest form of nature conservation was born from the belief that the landscape lives, and that nature is inseparable from ourselves. Landscape commons were an inherent expression of this belief (Olwig 2013). To elucidate this I make a short detour to an area where this is still operational, although threatened as well. The Karakol Valley in southern Siberia, the centre of the Eurasian continent, may serve as an example for reappraisal of the commons in Europe (Fig. 2). For the Altai Indigenous People, native identity grows out of the land. The Karakol Valley represents the spiritual heart of the Altai Republic (Dobson \& Mamyev 2010). Through the ages, its natives have taken great care to protect the valley from harmful practices. A wonderful wealth of stories explains the sacredness of specific places, objects and living beings, the role of spirits in daily life, and the guidelines for behaviour. The Altaian worldview can be summarised in three rules of thumb: to just undertake actions that have meaning, to take care of the right timing of everything to happen, and to keep measure and proportion, never taking more from nature than one needs (personal communication, Anatoliy M. Unukov, August 2016). Such key concepts of respect, balance and harmony immediately make clear why the Altai culture is often completely at odds with the modern Russian and Western utilitarian paradigm that we generally tend not to question.

For the Altai culture, a modern culture within the Russian Federation, profit maximisation is an alien concept. Even if we were to consider embarking on new landscape commons, this is already made difficult because Western culture does not fully appreciate our relationship to nature and landscape with embedded natural and cultural heritage. Still, although the landscape commons in Europe have been enclosed almost everywhere (Olwig 2013), there are clear tendencies of revaluation of rights of use instead of exerting ownership rights. Commonly accessible heritage can bring people together in joint efforts to use the inherited landscape as a resource for social returns on investment (Manetti et al. 2015) to be shared and cherished rather than conserved by regulating ownership. 


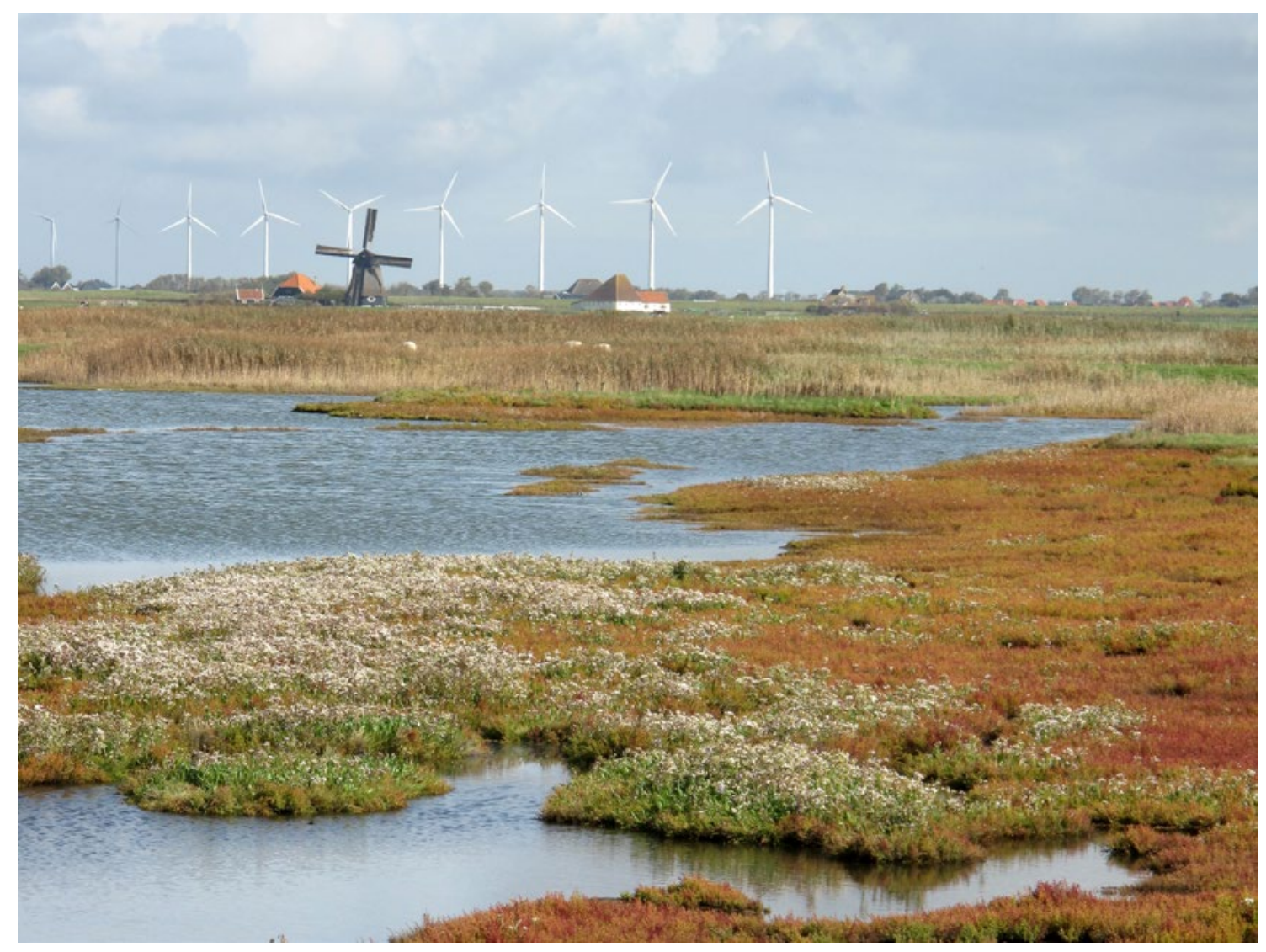

Figure 3. Wetland area offering space to rare bird species in an age-old polder landscape in North-Holland, today adopted by Natuurmonumenten.

The regulations to open up the parks and private properties of Dutch country estates and manors to the public, in return for subsidy grants and tax advantages, already have a long history (Arnouts et al. 2012). The success of the National Trust in England as a membership organisation was based on the work of the Commons Preservation Society which had fought legal battles to save common land and stretches of countryside in the second half of the nineteenth century (Lowe 2017), a model that was also followed later in the Netherlands with the Dutch sister organisation Natuurmonumenten (Beintema \& Beintema 2005; see Fig. 3). Today, profit maximising models in heritage tourism are increasingly being criticised for their neglect of local and universal interests (Alvarez-Sousa 2018). Landscape and heritage conservation institutions in various countries - ranging from public, semi-public to private - are currently focussing on new business models (based on the new paradigm of a sharing economy) that benefit from local resources, particularly through tourism (Romao \& Neuts 2017; Zavratnik et al. 2018) and urban farming (Pölling et al. 2017), in a more balanced way.

Further examples include urban farming initiatives all over Europe and beyond (Mok et al. 2014; Pölling et al. 2017) as well as environmental cooperatives in the Netherlands (Termeer et al. 2013; Tregear \& Cooper 2016), rewilding projects (Pereira \& Navarro 2015), and the huge commitment of many landscape volunteers and stewards, especially in the UK, Norway and the Netherlands (Raymond et al. 2016). In all of these examples, cultural heritage and natural heritage are considered as inherent values of the landscape. They represent inspiring bottom-up actions of citizens and landowners, within an open governance context, to take responsibility for the heritage present. 


\section{Reflection and conclusion}

It is not due to the lack of appreciation that people (inhabitants, land managers, tourists, and landowners alike) fail to actively foster natural and cultural heritage values in the landscape, but rather, it is the lack of awareness that a sustainable future for these values is far from secure, even when market-based instruments are being used for safeguarding public goods (Cooke \& Moon 2015; Ruoso \& Plant 2018). Increasing awareness about the entire chain of effects of land use change - including environmental costs of transport, energy consumption, pollution, weathering and wearing, and disruption of local communities - may lead to the revaluation of landscape commons. Since European governments are generally not very keen on community-based initiatives that supposedly undermine private property rights, awareness raising will have to come from bottom-up approaches. This is a clear task for the research community as well, to provide credible information and critically follow the promising initiatives in close cooperation with citizens' organisations and land managers.

In accordance with the philosophy of the Florence Convention (COE 2000) and the Faro Convention (COE 2005), heritage is everywhere, including everyday landscapes. This paper may have made clear that to prevent the gradual vanishing of today's museum landscapes figuring as tourist traps rather than as living landscapes (Gullino \& Larcher 2013), the heritage discourse in landscape management practice should be much more about the future than the past (González 2015). This builds upon the idea of landscape biography, aiming at " a better integration of historical landscape research with urban planning, landscape design and public participation in local and regional developments" (Kolen et al. 2015: 21). Clear visions are needed to persuade the decision makers to invest in a more equitable and sustainable appreciation of the embedded natural and cultural heritage. Since today's globalised market does not seem capable of sustainably managing heritage values in the landscape, a focus on rights of use instead of ownership rights is needed (Ferwerda 2015). Land can be owned, not landscape (with its embedded natural and cultural heritage). For the common good that landscape embodies, non-governmental organisations will need to take the responsibility, implying a clear knowledge brokerage challenge for the specialists and academics, and for museums and landscape observatories! Natural and cultural heritage are two sides of the same coin, together allowing identity to develop (Gullino \& Larcher 2013). New landscape commons may be the carriers of such identity.

\section{References}

Agnoletti, M. \& Emanueli, F., (eds), 2016. Biocultural Diversity in Europe. Switzerland: Springer Nature.

Agnoletti, M. \& Rotherham, I.D., 2015. Landscape and biocultural diversity. Biodiversity and Conservation 24(13), 3155-3165.

Alvarez-Sousa, A., 2018. The problems of tourist sustainability in cultural cities: sociopolitical perceptions and interests management. Sustainability 10(2), 503.

Antrop, M., 2004. Landscape change and the urbanization process in Europe. Landscape and Urban Planning 67(1-4), 9-26.

Antrop, M. \& Van Eetvelde, V., 2017. Landscape Perspectives. The Holistic Nature of Landscape. Dordrecht The Netherlands: Springer Nature.

Arnouts, R., van der Zouwen, M. \& Arts, B., 2012. Analysing governance modes and shifts-Governance arrangements in Dutch nature policy. Forest policy and economics 16, 43-50. 
BeILIN, R. \& Bohnet, I.C., 2015. Culture-production-place and nature: the landscapes of somewhere. Sustainability Science 10(2), 195-205.

Beintema, A. \& Beintema, N., 2005. Het begon met het Naardermeer: 100 jaar natuurmonument. Fontaine.

Bodenhamer, D.J., Harris, T.M. \& Corrigan, J., 2013. Deep mapping and the spatial humanities. International Journal of Humanities and Arts Computing 7(1-2), 170-175.

Buttimer, A., 2015. Home, Reach and the Sense of Place, in: A. Buttimer \& D. Seamon (eds), The human experience of space and place. Oxon and New York: Routledge, 166-187.

COE, 2000. European Landscape Convention (Florence Convention). Treaty Series Nr. 176.

COE, 2005. The Framework. Convention on the Value of Cultural Heritage for Society (Faro Convention). Treaty Series Nr. 199.

Cooke, B. \& Moon, K., 2015. Aligning 'public good' environmental stewardship with the landscape-scale: adapting MBIs for private land conservation policy. Ecological Economics 114, 152-158.

Dietz, T., Ostrom, E. \& Stern, P.C., 2003. The Struggle to Govern the Commons. Science 302(5652), 1907-1912.

Dobson, J. \& Mamyev, D., 2010. Sacred valley, conservation management and indigenous survival: Uch Enmek Indigenous Nature Park, Altai Republic, Russia, in: B. VerschuUreN (ed.), Sacred natural sites: Conserving nature and culture. Routledge, 244-262.

Elands, B., Vierikko, K., Andersson, E., Fischer, L., Gonçalves, P., Haase, D., Kowarik, I., Luz, A., Niemelä, J. \& Santos-Reis, M., 2018. Biocultural diversity: A novel concept to assess human-nature interrelations, nature conservation and stewardship in cities. Urban Forestry \& Urban Greening. https://doi.org/10.1016/j.ufug.2018.04.006.

Elands, B.H. \& Van Koppen, C.K., 2012. Biocultural diversity in the Netherlands: from ecologically noble savages towards biocultural creatives, in: B. ARTs, S. van Bommel, M. RosTonen \& G. Verschoor (eds), Forest-people interfaces. Springer, 181-193.

Fagerholm, N. \& KÄyHKÖ, N., 2009. Participatory mapping and geographical patterns of the social landscape values of rural communities in Zanzibar, Tanzania. Fennia-International Journal of Geography 187(1), 43-60.

FERWERDA, W.H., 2015. 4 returns, 3 zones, 20 years: A Holistic Framework for Ecological Restoration by People and Business for Next Generations. Erasmus University, Rotterdam School of Management, Series on Positive Change, Volume 1.

GonzÁlez, P.A., 2015. Conceptualizing Cultural Heritage as a Common, in: P.F. BieHL, D. C. Comer, C. Prescott \& H. A., Soderland (eds), Identity and Heritage. Cham: Springer.

Gullino, P. \& LarCher, F., 2013. Integrity in UNESCO World Heritage Sites. A comparative study for rural landscapes. Journal of Cultural Heritage 14(5), 389-395.

Hardin, G., 1968. The tragedy of the commons. Science 162, 1243-1248.

Holtmeier, F.K. \& Broll, G., 2005. Sensitivity and response of northern hemisphere altitudinal and polar treelines to environmental change at landscape and local scales. Global ecology and Biogeography 14(5), 395-410.

Kolen, J., Renes, J. \& Hermans, R. (eds), 2015. Landscape biographies: geographical, historical and archaeological perspectives on the production and transmission of landscapes. Amsterdam University Press. Lähdesmäki, T., Passerini, L., Kaasik-Krogerus, S. \& Van Huis, I. (eds), 2019. Dissonant Heritages and Memories in Contemporary Europe. Cham, Switzerland: Palgrave Macmillan.

Latour, B., 2004. Politics of nature: how to bring the sciences into democracy. Cambridge, Massachusetts: Harvard University Press.

LOWE, P., 2017. The rural idyll defended: from preservation to conservation, in: G. E. MINGAY 
(ed.), The rural idyll. Routledge, 113-131.

MacDonald, D., Crabtree, J. R., Wiesinger, G., Dax, T., Stamou, N., Fleury, P. et al., 2000. Agricultural abandonment in mountain areas of Europe: environmental consequences and policy response. Journal of Environmental Management 59, 47-69.

Mandl C.E., 2019. Managing Complexity in Social Systems. Management for Professionals. Cham: Springer.

Manetti, G., Bellucci, M., Como, E. \& Bagnoli, L., 2015. Investing in volunteering: measuring social returns of volunteer recruitment, training and management, VOLUNTAS: International Journal of Voluntary and Nonprofit Organizations 26(5), 2104-2129.

MAY, D.E., 2015. Rethinking the conflict between landscape change and historic landscape preservation. Journal of Heritage Tourism 1-5. http://dx.doi.org/10.1080/174387 3x.2015.1047374.

Metzger, M.J., Lindner, M. \& Pedroli, B., 2018. Towards a roadmap for sustainable land use in Europe. Regional Environmental Change 18(3), 707-713.

Mok, H.-F., Williamson, V.G., Grove, J.R., Burry, K., Barker, S.F. \& Hamilton, A.J., 2014. Strawberry fields forever? Urban agriculture in developed countries: a review. Agronomy for Sustainable Development 34(1), 21-43.

Olwig, K.R., 2013. Globalism and the Enclosure of the Landscape Commons, in: I.D. Rotherham (ed.), Cultural Severance and the Environment. Dordrecht: Springer, 31-46.

Ostrom, E., 1990. Governing the commons: the evolution of institutions for collective action. Cambridge: Cambridge University Press.

Palang, H. \& Fry, G., 2003. Landscape interfaces: Cultural heritage in changing landscapes. Springer Science \& Business Media.

Pedroli, B., Rounsevell, M., Metzger, M., Paterson, J. \& the VOlante consortium, 2015. The VOLANTE Roadmap towards sustainable land resource management in Europe. VOLANTE final project document. Alterra Wageningen UR, 24 pp. www.volante-project.eu/ docs/roadmap.pdf.

Pedroli, B., Pinto Correia, T. \& Primdahl, J., 2016. Challenges for a shared European countryside of uncertain future. Towards a modern community-based landscape perspective. Landscape Research 41(4), 450-460.

Pereira, H.M. \& Navarro, L.M., 2015. Rewilding European landscapes. Springer.

Pérez-Soba, M., Paterson, J., Metzger, M.J., Gramberger, M., Houtkamp, J., Jensen, A., Murray-Rust, D. \& Verkerk, P.J., 2018. Sketching sustainable land use in Europe by 2040: a multi-stakeholder participatory approach to elicit cross-sectoral visions. Regional Environmental Change 18(3), 775-787.

Pounds, N. J., 1990. An Historical Geography of Europe - Abridged Version. Cambridge: Cambridge University Press.

Pinto Correia, T., Primdahl, J. \& Pedroli, B., 2018. European Landscapes in Transition. Implications for Policy and Practice. Cambridge: Cambridge University Press.

Plieninger, T., Draux, H., Fagerholm, N., Bieling, C., Bürgi, M., Kizos, T., Kuemmerle, T., Primdahl, J. \& Verburg, P.H., 2016. The driving forces of landscape change in Europe: A systematic review of the evidence. Land Use Policy 57, 204-214.

Plieninger, T., Kizos, T., Bieling, C., Le Du Blayo, L., Budniok, M.-A., Bürgi, M., Crumley, C.L., Girod, G., Howard, P., Kolen, J., Kuemmerle, T., Milcinski, G., Palang, H., Trommler, K. \& Verburg, P.H., 2015. Exploring ecosystem-change and society through a landscape lens recent progress in European landscape research. Ecology and Society 20(2). http://dx.doi.org/10.5751/ES-07443-200205. 
Pölling, B., Prados, M.J., Torquati, B.M., Giacchè, G., Recasens, X., Paffarini, C., Alfranca, O. \& Lorleberg, W., 2017. Business models in urban farming: A comparative analysis of case studies from Spain, Italy and Germany. Moravian Geographical Reports 25(3), 166-180.

Primdahl, J. \& Kristensen, L.S., 2016. Landscape strategy making and landscape characterisation-experiences from Danish experimental planning processes. Landscape Research 41(2), 227-238.

Priore, R., 2009. No People, No Landscape. La Convenzione europea del paesaggio: luci e ombre nel processo di attuazione in Italia. Milano: FrancoAngeli.

Raymond, C.M., Bieling, C., Fagerholm, N., Martin-Lopez, B. \& Plieninger, T., 2016. The farmer as a landscape steward: comparing local understandings of landscape stewardship, landscape values, and land management actions. Ambio 45(2), 173-184.

RoberTS, L., 2016. Deep Mapping and Spatial Anthropology. Humanities 5(1), 5. http:// dx.doi.org/10.3390/h5010005.

Romao, J. \& Neuts, B., 2017. Territorial capital, smart tourism specialization and sustainable regional development: Experiences from Europe. Habitat International 68, 64-74.

Ruoso, L.-E. \& Plant, R., 2018. A politics of place framework for unravelling peri-urban conflict: An example of peri-urban Sydney, Australia. Journal of Urban Management 7(2), 57-69. Serra, P., Pons, X. \& Saurí, D., 2008. Land-cover and land-use change in a Mediterranean landscape: a spatial analysis of driving forces integrating biophysical and human factors. Applied Geography 28, 189-209.

Stobbelaar, D.J. \& Pedroli, B., 2011. Perspectives on Landscape Identity: A Conceptual Challenge. Landscape Research 36(3), 321-339.

Termeer, C.J., Stuiver, M., Gerritsen, A. \& Huntjens, P., 2013. Integrating self-governance in heavily regulated policy fields: insights from a Dutch Farmers' Cooperative. Journal of Environmental Policy \& Planning 15(2), 285-302.

Tregear, A. \& Cooper, S., 2016. Embeddedness, social capital and learning in rural areas: The case of producer cooperatives. Journal of Rural Studies 44, 101-110.

Van der Sluis, T., Pedroli, B., Kristensen, S.B.P., Lavinia Cosor, G. \& Pavlis, E., 2015. Changing land use intensity in Europe - Recent processes in selected case studies. Land Use Policy 57, 777-785.

Zavratnik, V., Kos, A. \& Stojmenova Duh, E., 2018. Smart Villages: Comprehensive Review of Initiatives and Practices. Sustainability 10(7), 2559. 